Svetlana Mihić ${ }^{1}$

Univerzitet Edukons, Fakultet poslovne ekonomije,

Sremska Kamenica

Danijela Dašić

Univerzitet Novi Sad, Ekonomski fakultet, Subotica

Dejan Supić ${ }^{3}$

Univerzitet Edukons, Fakultet poslovne ekonomije, Sremska Kamenica
SCIENTIFIC REVIEW ARTICLE doi:10.5937/ekonomika1502069M

Received: February 25, 2015

Accepted: March 26, 2015

\title{
MARKETING APPROACH TO E-DISTRIBUTION OF MODERN BANKING PRODUCTS
}

\begin{abstract}
Modern technological progress changes the way of business and have great impact on business effectiveness and efficiency. Influence of Internet on banking is huge and a lot of banks are motivated to change business strategy in order to keep the competitiveness in the modern market. Besides, internet banking brought in new clients and requests in terms of having more flexible and less expensive business. The main goal of this study is to show clients satisfaction with services which are the result of modern marketing in banking as well as customer loyalty and the end result is the realization of profits in the banking sector. During this research it was used combined questionnaire-Likert's scale as well as other statistical methods. Research results show, also, the next step needed for successful implementation of modern business methods. It would be a financial indicator of service quality (before use of marketing strategies and distribution channels) as well as those indicators which would be received after distribution of banking services and products. Modern banking should find its own base with new technologies which are moving point of distribution from supplier towards the customer / client.
\end{abstract}

Key words: marketing, banking, customer satisfaction, internet

JEL classification: M3, O33

\section{НОВИ МАРКЕТИНГ ПРИСТУП ДИСТРИБУЦИЈЕ САВРЕМЕНИХ БАНКАРСКИХ ПРОИЗВОДА}

\begin{abstract}
Апстракт
Убрзан развој интернета мења начин пословања савремених банака и на тај начин омогућава различите погодности и предности уз повећање ефикасности и ефективности пословања. Утицај интернета на банкарство
\end{abstract}

\footnotetext{
${ }^{1}$ svetlanamihic@gmail.com

2 danijela.dasic@gmail.com

3 dejan.supic@educons.edu.rs
} 
је огроман, па је велики број банака мотивисан да измени своје стратегије пословања како би остале конкурентне на савременом тржишту. Поред тога, савремено интернет банкарство донело је банкама и читав низ нових захтева корисника услуга у смислу повољнијег и флексибилнијег пословања које традиционално банкарство није могло да им понуди. Циљ истраживања овога рада јесте да се прикаже задовољство клијената услугама које доноси савремени маркетинг у банкама као илојалност клијената, а крајњи резултат је остваривање профита у банкарском сектору. Приликом истраживања коришћен је комбиновани упитник - Ликертова скала, као и друге савремене статистичке методе. Истраживањем су добијени резултати који указују на даље кораке којих би се требали придржавати како би имплементација савремених метода пословања била што успешнија. Даља истраживања која би се могла извести из наведеног су финансијски показатељи квалитета услуге пре коришћења маркетинг стратегије и савремених метода дистрибуичје банкарских производа као и они које би добили након примене модерне дистрибуиије. Савремено банкарство своју упоришну тачку треба управо да пронађе у новим технологијама које ће тежиште дистрибуције померити са тачке понуђача на тачку клијента/корисника банкарских услуга.

Кључне речи: маркетинг, банкарство, сатисфакција клијената, интернет

\section{Introduction}

In condition of globalization and competition, the imperative of each bank is to reach customers' needs and their requests; it is the main condition for bank existence, development and growth. Source of competitive advantage banks have in well-designed and well applied marketing concept. It means that banks must go ahead with technology and modern marketing in banking. The bank is mediating company. (Šljivančanin, 2000.) Beside profit, bank's goal is to provide continual market growth as well as development. Competition makes it difficult. During past years, we all are witnesses of globalization and technological modernization as well as IT literacy. Modern business world with a high level of competition and cruel fight for customers causes necessity for rational and innovative politics in the area of banking offers and it is the main condition for longlasting growth, high market share, high profit and client satisfaction. (Djordjević, 2009.) Financial institutions need to change business behavior because of modern banking trends. Basic marketing technologies in banking are: Internet marketing and Internet banking, mobile banking, social networking sites, QR codes, socially responsible business, etc. Market-developed countries have strategic and operative bank planning based on marketing practice.

This study, also, shows modern marketing trends, measurement of client satisfaction as well as modern technologies. The second part of the study analyzes modern marketing in particular banks in Novi Sad. The Likert's scale has been used in a research as a combined questionnaire with respondents' suggestions. The study explores the problems of clients' satisfaction with modern marketing tools - their disadvantages and advantages - in order to show the connection between results and customer loyalty. 


\section{Challenges of use new technologies in banking}

The internet and its mass use, as well as effective software solutions, made internet the most common communication channel among business banks and clients. Traditional way of communicating has been overcome and very slow - regardless of whether we are talking about promotion activities, credit approval or any kind of banking products. Possibilities of internet implementation into credit procedures and processes are numerous. This way of communicating must be available to clients, economical, protected from abuse and coordinated with regulation - all this in function of becoming an internet crucial and a multimedia resource, incorporated into business banks. (Ranisavljević, 2014.) However, it is important to mention that internet cannot replace a personal relationship with clients - they must be brought to the bank; that is the only way for achieving customer satisfaction and their loyalty. Launching new communication technologies like automatization in business banking give numerous possibilities in developing and offering new products and services but, also, it allows lower costs. Advantages can be summed up in the following ways:

- Numerous empirical research showed that multiple cost reduction in banking is/was done by new technological innovations in the product/service industry;

- Innovations in services and banks that are accepting them achieve a bigger market share by applying these innovations;

- Mass communication became possible with both loyal and potential clients, all this with lower charges;

- Communication with clients is not limited by place and time; using web pages with possibility of marketing promotion;

- Innovations are related to wider product assortment and to new products/ services (for example, new can be (re) opened via the internet any time, without going to the bank;

- It has stimulated development of new banking activities which are not typical (insurance, leasing, securities trading etc.).

If banks intend to be successful they must improve service even at the cost of enlargement costs. (Ljubojević, 2000.) Customer as the most important resource is the greatest factor in banking. (Hoffman \& Bateson, 2011.) Modern marketing philosophy can be expressed as achieving goals through customer satisfaction. (Jobber \& Fany, 2006.) Creating satisfaction and loyalty is the hardest task of marketing oriented banks. All bank activities must be oriented toward customers. (Vunjak \& Kovačević, 2006.) Bank's ability to achieve a high level of constant clients depends on business goals and its redefinition. Client's satisfaction is one of the most significant goals and concepts of modern banking. (Zelenović, 2012.) Satisfaction, especially the satisfaction with service quality affects the clients' choice of bank. Higher satisfaction is bound to the unbreakable relation among bank and client and it is a way how competition can be neutralized. One of the keys of keeping customers is their satisfaction and it is resource for attaching new clients and this is the main obligation in banking. Banks must work harder on it. Loyalty and satisfaction are tightly connected. According to Ljubojević (2000, p. 69) "Satisfaction is the key element in the process of creating and improving loyalty. Beside this, feedback with customers is the key element in measuring and managing customer satisfaction." So, according to this definition, satisfaction 
is a function of perception and expectations. (Vunjak, 2001.) Expectations are built through previous experience about service and they can be considered as the probability of an event; perception is considered as event estimation in the process of service delivering. What is characteristic in banking is the fact that service perception is based on perception of assembly services as well as on the way of service offering by a bank staff. Without satisfaction, bank cannot achieve profit and because of this, banks must make best effort to educate clients. However, new technologies increase and less clients come to the bank, which makes relation client-bank more difficult. Long-lasting relationships are necessary and loyalty is a part of it. Key factors for these relationships are: focus on clients needs, personal relationship, exceeding clients' expectations, successful contracts, positive attitude and interest for clients needs and problems. (Michaud, 2000.) However, satisfied client is not always guarantee for business success. What makes the difference between banks is loyalty. Loyalty is crucial beside high service quality which is based on employees in banking. (Dašić, Mihić\&Supić, 2014.) If clients are satisfied with banking service, with employees and with all service aspects, it is assumed that clients will be loyal and they will not for sure - carry loyalty over other people/clients of the same financial institution. If clients are not satisfied with any aspects of service, loyalty cannot be achieved. Satisfied clients can always change the bank if they estimate that other banks (competitors) can satisfy them better and to a greater extent. With time, client satisfaction decreases whether due to higher expectations or due to weaker brand performances. Because of that, there is the belief that only thrilled customer is the one who is the base of loyalty and fidelity.

Not only that, those clients use products/service but they, also, spread up positiveness and bring new clients. Satisfaction is a condition for loyalty as well as the main component of loyalty during the first meeting between client and financial institutions. (Veljković, 2009.) The function of customer research is to find out new solutions for keeping current clients and bringing new ones; satisfaction is the way for it (service quality and employees) but if banks want to make long-term profit satisfaction must lead to the loyalty. It is important for companies to create marketing strategies which will not only satisfy but exceed client needs and expectations. (Maričić, 2005.) Marketing makes a contribution to this, directly. (Lamb, Hair \& McDaniel, 2013.) Only with a base of loyal clients' bank can count on profit growth and long-lasting profit. (Butler, 2004.) Trust and closeness with clients are more important than loyalty. The successful marketing relationship is based on commitment, trust and communication. (Mihić, Andrejević \& Mihajlović, 2012.) In the modern business world, client satisfaction is one of the main goals of marketing, but it is, also, tool for achieving other business goals such as profit, market share, degree of loyalty (Maričić, Veljković \& Djordjević, 2012.) Experiences of developed countries say about the importance of client education (Mihić, Andrejević \& Mihajlović, 2012.) To keep pace with technology, bank had to accept and apply new ways of business as well as a new way of marketing.

\section{Internet banking}

Huge technological and communication progress had great effect on the banking sector. Banking is the area supported by information technology and IT allows banks to make a difference in services. Constant innovation and improvement in service depend 
on it. Because of that, a lot of banks have been motivated to change business strategies in order to keep the competitiveness in the market. Technology is the key factor for changes in banking in the future. (Mols, 2000.) New technological advances are (beside others): smart cards, cash machines, phone banking, internet banking, mobile banking, etc. Internet is cheap and accessible and this is the reason why users are determined to use this kind of banking. Internet banking allows clients to do their transactions any time at any place which absolutely decreases transaction costs. (Carlston, Furst \& Nole, 2000.) Also, internet and its influence on the economy - in general - has been seen as a technology that dramatically affects banking marketing.(Kotler\& Keller,2006.) For bank, the internet is additional channel for service distribution, promotion and marketing improvement. Direct marketing and marketing of customer relationship are based on the databases which are built thanks to the internet. Internet banking is the fastest, most economical and most effective way of banking business. Thanks to this, the banking business is available 24 hours per each day during the whole year. Business tempo is dictated by clients, of course. Advantages of internet banking are following: (Zelenović, 2012.): working hours, unlimited place dimension, speed of transactions and estimation of transactions.

\section{Mobile banking}

Mobile banking is a part and the newest trend in electronic banking. This kind of banking allows transactions through a mobile phone with internet connection (smart phones). About $97 \%$ citizens in Serbia at the age of 15 or older are active users of mobile phones. (Petković, 2014.) Mobile marketing is relatively new part of digital marketing and it means use of mobile devices as the main communication channel from brand to the customer (from bank to client and vice versa). Advantages are following: availability, customer loyalty, possibility of personalization, possibility of geographical location and coordinates, functionality of mobile devices as well as video calls, calendar, cameras, internet, etc. Speaking of banking, MMS and SMS marketing are included as well as m-banking, websites, mobile applications and QR codes. (Explanation of QR codes will be a bit later.) Appearance of new platform like "android" and "IOS" changes bank business. Beside mentioned kinds of mobile marketing, there are banks in the world which brought in new application called "take a photo and pay"- application that is only used by the Erste Bank in Serbia. This application is revolutionizing the way clients pay their bills and it also decreases queues in banks. The same by using this application, unnecessary paper and archival space are saved. (Dašić, 2013.) Mobile banking is a service that allows clients to do online payment without their presence at the bank and without papers. Taking photo of bill and transmitting it into a mobile application "android", iPhone or $i P a d$ by which photo is automatically read, you can pay by pressing one button. Mobile banking is revolution of modern technology and having in mind technological trend and speed of it, bank must follow marketing changes, all in order to satisfy customer needs and wishes. 


\section{Qr codes}

By following new technological and communication advances, the banks brought into system of using QR codes which allow clients to communicate simply and faster with the bank. Thanks to these codes customers are able to arrange meeting with bank staff when they want and the main tool for that is the smart phone. During registration of code, phone converts QR code into the appropriate URL address and by doing that, the customer is redirected to a web site he/she wants. To explain this precisely, customer does not have to enter URL address in order to access to the a web page; it is enough to scan (by own mobile phone) QR code and it redirects customers to connect internet page where she/he can find all needed information related to the bank. Clients and other people interested in this are now able to arrange meeting with a bank worker (of course, you have to fill in some basic information about yourself, such as first name, first letter of surname, phone contact, date and time, town or municipality). QR code - which is originally two-dimensional square bar code read by optical scanners is a significant technological invention on the Serbian market. By using this innovative communication channel banks show commitment and high devotion to own clients. Of course, the fact that most people already use or intend to use smart phones is absolutely plus for QR technology. These bank codes can be found on ad posters, billboards, flyers; at bus stations and on traffic vehicles as well as on websites.

\section{Social networking sites}

Today's time of globalization and fast life without enough free time contribute to relation between banks and social networking sites. Introducing of banking through these sites allows a different approach to clients depending on how the client wants to be visible on these sites. If the bank allows for clients to communicate through site - no matter whether it is via camera or in writing - that kind of communication will affect the number of visitors such as the number of satisfied potential clients. Market share and bank profit can be significantly increased by the way of bank promotion on social networking sites. (Dašić, 2014.) It is important to get the most out of sites and that will be possible way of making profit through communication and customer satisfaction. Speaking of which, there are not any parts of business and life where social networking sites cannot be applied - communication, public relations, branding, promotion, etc. Regarding banking, we will address only Facebook, Myspace, Foursquare, Google Plus, LinkedIn and Twitter which is, by the way, micro blog, but Twitter is, after Facebook, the most widespread social network and we cannot avoid it as well as YouTube which is the site for content sharing but it is often used in banking. (Lamb, Hair\& McDaniel, 2013.) Some studies show that $60 \%$ of banks looks at social networking sites as a useful way in establishing and maintaining contacts with clients while $30 \%$ of banks has an attitude that social networks, as less expensive and useful marketing tool, allow communication with clients and find out what clients need and want. Of course, these banks use social networks as a great way to come to clients and make an offer to them in order to satisfy them and make clients loyal. (Rađenović, Mihić, Mihajlović, 2014.) About 10\% of 
banks- those ones with business loss - does not look at sites with gratitude so they do not use it in business. Research also, shows that Facebook is one of the most useful social networking sites and a lot of banks use this network. (Mayfield, 2008.) Social sites are an unavoidable part in banking. There is the belief that social sites will eliminate virtually bank networks. Others believe that sites will destroy banks due to inadequate communication. Although, it is certain that social sites will make revolutionary change in banking, especially in the field of customer relationship. The best example of social site benefits in banking is America and China where interaction with clients is dramatically changed with the following benefits (Hoffman \& Marek, 2010): active client developing and understanding, fast answers, following trends in world and decreasing customers' charges. Marketing of social sites has more than 800 million potential users on sites like Facebook, Twitter, YouTube, Foursquare, etc.These users share their opinion about products and service and in that way they increase the brand popularity and the number of bank fans. One of the main advantages of these social networking sites is ability of sharing information very fast through clients' networks.

\section{Development and determinants of Serbian banking}

In Serbia, there are 29 banks. Banks with bigger profit, according to the balance sheet since 2013 are following: Intesa Bank-6.6; Raiffeisen Bank-5.3; Unicredit Bank4.3; Komercijalnabanka-4.0; ProCredit Bank-1.9. (all expressed in billion dinars). Banks with the biggest loss are the following: KBC Bank-5.6; NLB Bank -2.0; Alpha Bank-1.0; OTP Bank- 0.8; Piraeus Bank- 0.8. (All expressed in billion dinars.) According to the research, there is the list of banks with the best offer, working hours, relationship with customers, network of cash machines, best promotion and those results are shown below:

- The best offer: Bank Intesa, Komercijalna banka, AIK bank, UniCredit bank, Societe Generale bank, Raiffeisen bank, OTP bank, Sberbank, Erste bank, Alpha bank;

- The best customer relationship: Erste bank, Komercijalna banka, Sberbank, Raiffeisen bank, UniCredit bank;

- The best network of cash machines and offices: Bank Intesa, Erste bank, OTP bank, Komercijalna banka, Raiffeisen bank, AIK bank, Societe Generale bank, Uniredit bank;

- The best working hours: Bank Intesa, Komercijalna banka, Raiffeisen bank, AIK bank, UniCredit bank, OTP bank;

- Banks with the best presented offer: Raiffeisen bank, Bank Intesa, Komercijalna banka, Erste bank, AIK bank.

In Serbia, each bank has its own internet page, electronic payment, phone use in banking, net-banking services, e-banking, m-banking. Each bank promotes itself in different ways and each one is recognized differently. Some of the banks did step forward by following modern technology and by using e-commerce service, QRcodes, PayPass-non contact payment system with payment cards; also banks brought in service "take a photo and pay" as well as use social networking sites-all these in order to satisfy customers' needs. "Today, the internet is the global multimedia distributional 
information system that include, practically, all worlds and allow, not only access to multimedia contents, but also it generates specific multimedia contents according to particular requests in interactive mode.” (Radjenović, Mihić \& Mihajlović, 2014.) This is the way for banks being different from competitors and occupy a leading position in the modern banking world. In Serbia, the biggest growth of visitors to social networking sites has following banks: Erstebank, Aikbank, Intesabank, Komercijalna banka, OTP bank. On YouTube channel, the most common is Erste bank, which presents (on rented space) its own video clips, advertisements, campaigns, news as well as mini clips from the human resource department. Among all social sites, banks use LinkedIn the least, with a small number of visitors. This social site is at the beginning of development in Serbia while the Google Plus is even less in use; only Komercijalna bank with about $40 \%$ of followers has an account on this social network. The Erste bank uses SlideShare, Blog and Foursquare. These are five newest types of social networking sites in which banks can plan its showing until the end of 2015. As a conclusion to this topic, we can say that big and profitable bank with significant market share in Serbia understand very well the importance of social networks and by respecting it, modern technologies are an important part of their marketing strategy.

\section{Methodology and research results}

For the research purpose a survey has been done in the most famous banks in Novi Sad with the aim to show customer satisfaction with a bank service brought in by modern banking marketing. The main goal of this study is to show clients satisfaction with services which are the result of modern marketing in banking as well as customer loyalty and the final result is the realization of profits in the banking sector. At the same time, we will see potential (dis)advantages of bank services. The subject of research was service of the following banks in Novi Sad: Intesabank, Komercijalna bank, Raiffeisenbank, OTP bank and Erstebank. Research has been done, including 3500 respondents (only private persons); 700 respondents were asked in each bank in a period of 6 months, from march to august 2014. It is important to point out that the survey includes people at each level of education, wages and ages. Also, the study was done by using a combined questionnaire (anonymous and short) in function of getting most sincere answers without taking too much time. Questionnaires were personally done in business units of mentioned banks with the help of employees and after one done transaction. Results will be shown by the graph and per categories.

\section{Research results}

Research was applied in five banks. Results are shown for each bank individually; graph 1 shows a cumulative score of all five banks and satisfaction of respondents with each service individually. 


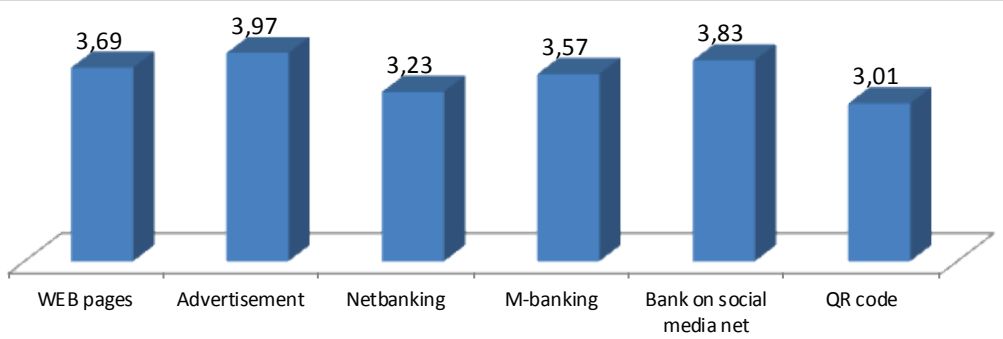

Graph 1. Cumulative score of respondents' satisfaction with modern bank services in Novi Sad Source: author's results

According to these results, banks should pay more attention to service of netbanking systems and QR codes. Reasons for customer dissatisfaction in these fields are: insecurity, tough registration, bad design, complicated use, bad application solutions, expensive service, problems with transactions, technology. Generally speaking, banks should improve electronic banking because it decreases crowd in offices and gives space to employees to be dedicated to other assignments in order to achieve bank's goals. By improving electronic banking, banks would be able not only to keep customers, but also to make long-lasting loyalty with them. If we are talking about QR codes in banking, this service is only at the beginning, but it has a lot of advantages. Customers are not satisfied with this service, mainly, because they do not know about these codes and they do not recognize the advantages of connecting bank and themselves by using QR codes. One of the ways for building consciousness and awareness of these codes is through special companies and promotion activities. As a result, banks would have less phone calls from clients and it would make calculation of credit worthiness easier because clients would come to bank with preparing documents. Research also shows that banks are not fully aware of QR codes advantages and for now, banks use this technology only for connection codes with bank internet site. Even is this full filled, there are problems with clients who are not able to find exactly what they need on site. Research shows customer satisfaction with services in mentioned banks by following order presented in graph 2 .

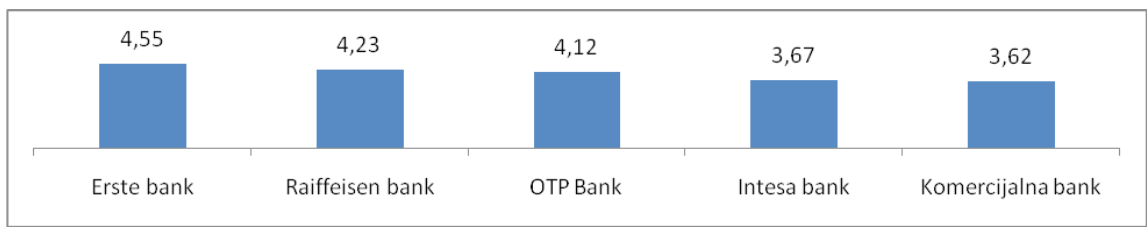

Graph 2. Customer satisfaction with web page of targeted banks Source: author's results

It can be seen that clients are the most satisfied with the appearance and content of Erste bank web page; almost the same results can be seen at Raiffeisen bank and OTP 
bank. It is said that pages of these banks have nice design and each of the pages has key elements fully implemented for clients. Clients are the least satisfied with the internet page of Komercijalna bank.

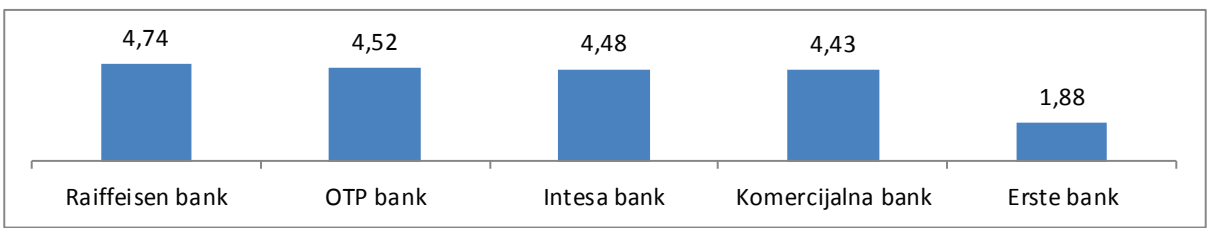

Graph 3. Customer satisfaction with content of advertisement Source: author's results

When it comes to the bank advertisement and its content, clients express the biggest satisfaction toward Reiffeisen bank commercial as well as OTP bank commercial. The main reasons are recognisability, connection with clients wishes and needs, ad sound and transmitted messages. In the Erste bank commercial, clients say that it is invisible, without appropriate content and users do not see the connection between commercial and bank service.

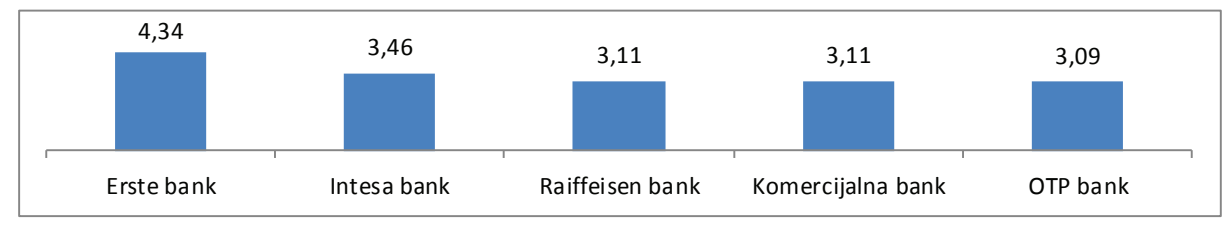

Graph 4. Customer satisfaction with Net Banking

Source: author's results

Regarding Net-Banking, satisfaction is the most expressed toward Erste bank because of design, functionality, easy registration, favorable prices. On the contrary, the least satisfaction is expressed toward OTP bank because of expensive service, old technology and problems during transactions.

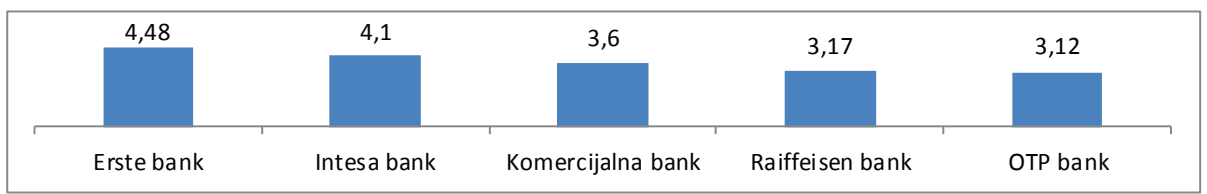

Graph 5. Customer satisfaction with M-banking

Source: author's results

Service of M-banking is the most appreciated by Erste bank and clients of this bank point out functionality, easy registration and especially service called "take a photo and pay". The OTP bank clients are the least satisfied, pointing out unavailability of service as well as price and complicated use. 


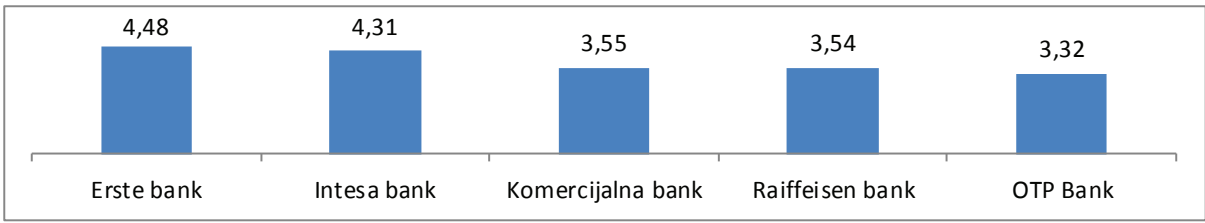

Graph 6. Customer satisfaction with contents and appearance of targeted banks on social networking sites

Source: author's results

Detailed research confirmed these results because Erste bank was the first with introduction on social networking sites and, for sure Erste bank has one of the largest visitor base. This bank is active on all social networks while other banks are available and active on one or two social networking sites. Once more, clients of OTP bank are the least satisfied, mainly because OTP bank was included itself relatively late into the social networking world and this is the reason why respondents could not be able to exactly express and measure their level of satisfaction.

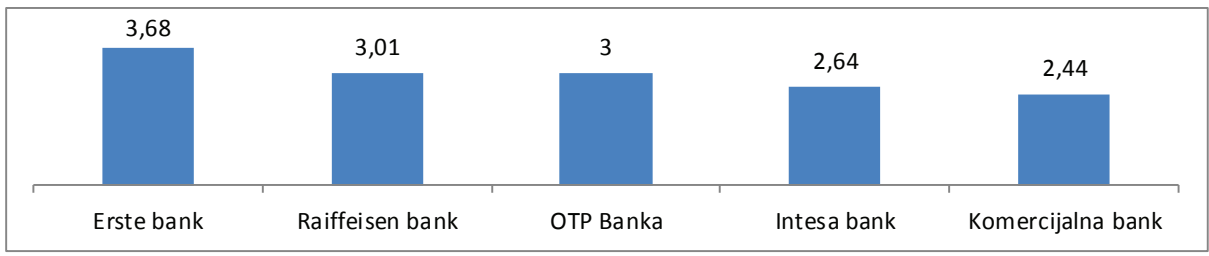

Graph 7. Customer satisfaction with QR codes of mentioned banks Source: author's results

Regarding the QR codes, the best result has Erstebank. The reason is a good and functional connection between codes and bank and great possibilities and information given by code scanning. Other banks have more modest results because QR codes are not used in an appropriate way and clients are not fully aware of the advantages and possibilities of mentioned codes.

Generally, clients are satisfied with their business banks. However, market research and different ways of services are absolutely desirable for banks to make clients fully satisfied. The last question in the questionnaire was: "Would You change Your business bank?" and it was close-type question. The majority of respondents has a negative answer which means general satisfaction with a modern banking system which, on the other side, points out the high level of loyalty built by business banks. 


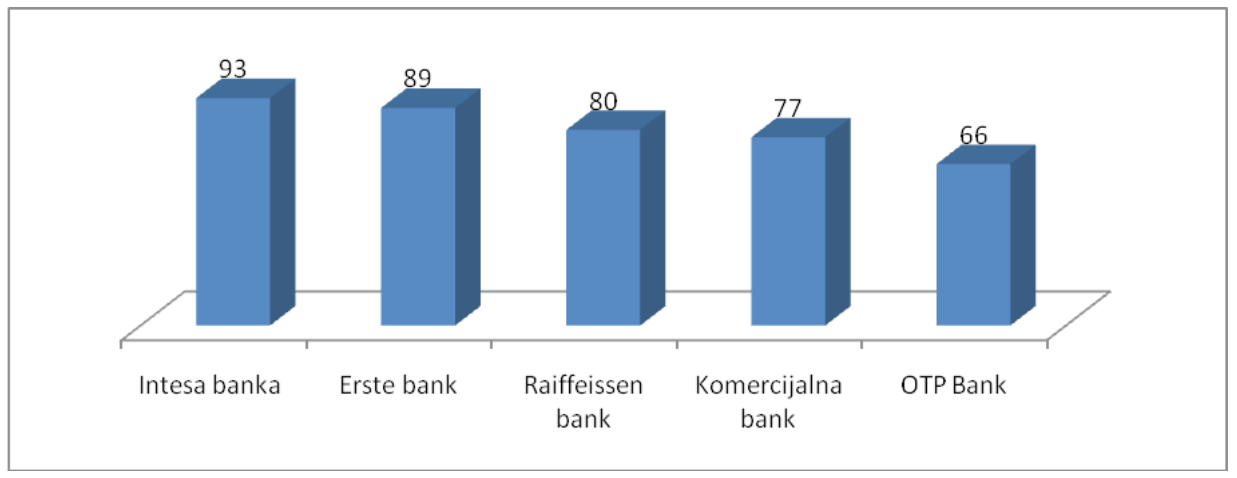

Graph 8. Level of customer loyalty

Source: author's results

Research shows that the biggest degree of loyalty have clients of the Intesa bank (93\% of them gave negative answer to the questions mentioned above). Other results are: Erste bank-89\%, Raiffeisen bank-80\%, Komercijalna banka-77\%. OTP bank-only $66 \%$ of respondents gave a negative answer so this bank should pay attention to this fact, having in mind that disloyalty means lower profit and client walk out. Although OTP bank clients are satisfied with a particular service, they are still not still attached to this bank. In addition to this, if results from the beginning are being compared, it can be seen that Intesa bank belongs to banks with the biggest profit in Serbia while OTP bank is the bank with loss in business.

\section{Conclusion}

Maintenance of high level customer satisfaction and long-lasting relationship with them are the most significant parts of the modern banking business. Constant communication and following customers' needs and suggestions should make it easier. Pull strategy as well as keeping customers through satisfaction model is the crucial task of each bank. The banking business is oriented toward customers with the main goal of making profit and reaching competitors advantage. To reach these goals banks need to use different marketing approaches in order to gain all available information about current and potential customers and about their needs, wishes and necessities. There are few methods for continuous monitoring and measurement of customer satisfaction, starting from book of impression and special questionnaires where customers can estimate bank work; through service which is given by employees in contact center and reclamation offices. The main aim of these activities is commitment to suggestions, questions and complaints in function of understanding customers' wishes and needs. The most reliable method to estimate satisfaction is studying for measurement of customer satisfaction. This is the practice used in most common banks in world recommended by most respected authorities in the marketing field. Regular annual implementation study of customer satisfaction is the part of business politics of each bank in Serbia; results of all studies are compared in function of exchanging experiences and taking best business practice. Results are also good base for understanding which is the base for planning the way of improving service quality and offers. One thing is certain - social networking sites and new technologies such as implementation QR 
codes basically change the terms and rules in banking world which should be advantage related to customer satisfaction. The research shows that customers want complete communication with banks through social network as well as online banking. Social network development shows few models of business bank that will change banking forever. Social networking sites will cancel and they already minimize the need for classical marketing and it its tools (billboard, TV commercial, etc.). Practice in developing social networking sites will allow banks to have a unique approach and unique package for each client. Attitude called "one offer for all" will disappear from banking, and service will match profile of each individual client. In addition to this, phone calls will be canceled and replaced by proactive banks on the Internet. Todays banks monitor social networking sites like Twitter, Facebook, and according to information found there, banks prepare business. Banks will be able to identify much more complaints and to solve it much faster than earlier in order to improve customer satisfaction. Today's banking business will last some time. Social sites will absolutely change it all. Bank units will take over complicated transactions such as housing loan. Parts of research presented above (shown with examples of five banks in Novi Sad) show how important is this matter. The main focus in banking is moving to quality of service and consequently, customer satisfaction becomes the key and main source of competitive advantage. This is a reason why banks constantly follow competitors' activities and changes - in order to adapt business to customer needs. Those banks, which businesses rely on satisfaction strategy have customer wishes and needs in the first place and satisfy them effectively and efficiently, better than competitors. Future in banking is in QR codes and in social networking sites which will replace commercial and electronic bankingpartially. The function of QR codes will be connected to social networking sites. In this way, limits of customer satisfaction will be moved higher and banking will have to deal with great challenges. Customer satisfaction is the most current in the banking sector, but in order to show real results of satisfaction, some of future research could show financial effects on bank business as well as marketing in banking.

\section{References}

Buttle, F. (2004.). Customer relationship management. Amsterdam: John Wiley\&sons. Carlston, J., Furst, W., \& Nole, D. (2000.). Internet banking. Society of Government Economists Conference, Washington DC.

Dašić, D. (2013.). Plaćanje računa aplikacijom "slikaj i plati” na android i IOS platformi, (pp.15-18). Palić, E trgovina.

Dašić, D. (2014.). Banke na društenim mrežama, (pp.17-21). Palić, E trgovina.

Dašić, D., Mihić, S., \& Supić, D. (2014.). Merenje kvaliteta usluge u bankama primenom tehnike tajne kupovine, Bankarstvo, 43(6), 120-146.

Đorđević, B. (2006.). Inovativni marketing u bankama - od invencije do komercijalizacije. Bankarstvo, 35(11-12), 66-76.

Hoffman, D., \& Marek, F. (2010.). Can You Measure the ROI of Your Social Media Marketing, Research Feature.

Hoffman, G. (1993). Customers Can Hone Mystery Shopping, Bank Marketing. 
Hoffman, K., \& Bateson, J. (2011.). Marketing usluga. Beograd: Data status.

Jobber, D., \& Fahy, J. (2006.). Osnovi markeringa. Novi Sad: SP Print.

Karlsson, V. (2004.). The book about Mystery Shopping. London: Better Word.

Kotler, P. (2006.). Marketing menadžment. Zagreb: Data status.

Kotler, P., \& Keller, K. (2006.). Marketing menadžment. Beograd: Data status.

Kotler, P., \& Keller, K. (2008.). Upravljanje marketingom. Zagreb: Mate.

Lamb, C., Hair, J., \& McDaniel, C. (2013.). Marketing-MKTG. Beograd: Data status.

Ljubojević, Č. (1998.). Menadžment i marketnig usluga. Novi Sad: Stilos.

Ljubojević, Č. (2000.). Marketing izazovi savremene banke. Beograd : Svet finansija.

Maričić, B. (2005.). Ponašanje potrošača. Beograd: Ekonomski fakultet u Beogradu.

Maričić, B. R., Veljković, S., \& Đorđević, A. (2012). Merenje satisfakcije potrošača. Marketing, 43(4), 235-244.

Mayfield, A. (2008.). What is Social Media. London.

Michaud, L. (2000., Novembar). Six keys to true client loyalty. Training \& Development.

Mihić, S., Andrejević, A., \& Mihajlović, M. (2012). Marketing odnosa - uloga i značaj u malim i srednjim preduzećima. Poslovna ekonomija, 6(1), 91-103.

Mihić, S., Andrejević, A., \& Mihajlović, M. (2012.). Savremeni potrošač i organska poljoprivreda u Srbiji. Ekonomika, 58(2), 13-22.

Mols, N. (2000.). The internet and services marketing-the case of Danish retail banking. Business Journal

Muller, J., \& Srića, V. (2005.). Upravljanje odnosom s klijentima : primjenom CRM poslovne strategije do povećanja konkurentnosti . Zagreb: Delfin.

Petković, A. (2014.). Mobilni marketing. http://marketingitd.com/2012/aleksandarpetkovic-mobilni-marketing-se-siri-i-u-regionu-ali-nedostaje-edukacija/

Radjenović, D., Mihić, S., \& M, Mihailović (2014.). Marketing E kastemerizacije i razvoj interneta-Srbija, Scientific Conference Sinergija 2014. (pp.101-104). Beograd: University Singidunum.

Ranisavljević, D. (2014.). Internet marketing u retail bankarstvu, Beograd: Singidunum-Sinteza.

Šljivančanin, M. (2000.). Banka-finansijsko predezeće. Podgorica: Ekonomski fakultet.

Veljković, S. (2009.). Marketing usluga. Beograd: Čugura Print-BG.

Vunjak, N. (2001.). Finansijski menadžment. Subotica: Ekonomski fakultet.

Vunjak, N., \& Kovačević, L. (2006.). Bankarstvo-Bankarski menadžment. Subotica: Proleter Bečej.

Zelenović, V. (2012.). Marketing u bankarstvu. Subotica: Proleter Bečej.

http://www.economy.rs. (24.12.2014).

http://www.snajderaj.com. (24.12.2014). 